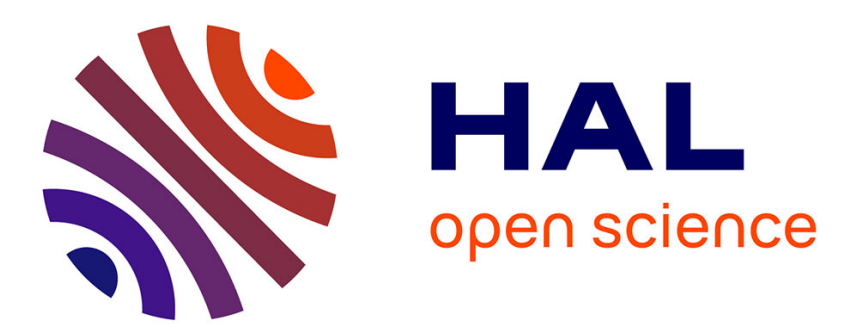

\title{
Ocher in Late Paleolithic Contexts at the Kovrizhka IV Site, the Baikal-Patom Highlands (Eastern Siberia, Russia)
}

\author{
A. V Tetenkin, E. I Demonterova, E. V Kaneva, Auréade Henry, E. Gauvrit
}

Roux

\section{To cite this version:}

A. V Tetenkin, E. I Demonterova, E. V Kaneva, Auréade Henry, E. Gauvrit Roux. Ocher in Late Paleolithic Contexts at the Kovrizhka IV Site, the Baikal-Patom Highlands (Eastern Siberia, Russia). Archaeology, Ethnology and Anthropology of Eurasia (Russian-language), 2020, 48 (3), pp.33-42. 10.17746/1563-0102.2020.48.3.033-042 . hal-02956085

\section{HAL Id: hal-02956085 https://hal.science/hal-02956085}

Submitted on 8 Nov 2021

HAL is a multi-disciplinary open access archive for the deposit and dissemination of scientific research documents, whether they are published or not. The documents may come from teaching and research institutions in France or abroad, or from public or private research centers.
L'archive ouverte pluridisciplinaire HAL, est destinée au dépôt et à la diffusion de documents scientifiques de niveau recherche, publiés ou non, émanant des établissements d'enseignement et de recherche français ou étrangers, des laboratoires publics ou privés. 
DOI: $10.17746 / 1563-0110.2020 .48 \cdot 3.033-042$

\author{
A.V. Tetenkin ${ }^{1}$, E.I. Demonterova ${ }^{2}$, E.V. Kaneva ${ }^{3}$, \\ A. Henry ${ }^{4}$, and E. Gauvrit Roux ${ }^{4}$ \\ ${ }^{1}$ Irkutsk National Research Technical University, \\ Lermontova 83, Irkutsk, 664074, Russia \\ E-mail: altet@list.ru \\ ${ }^{2}$ Institute of the Earth's Crust, \\ Siberian Branch, Russian Academy of Sciences, \\ Lermontova 128, Irkutsk, 664033, Russia \\ E-mail:dem@crust.irk.ru \\ ${ }^{3}$ Vinogradov Institute of Geochemistry, \\ Siberian Branch, Russian Academy of Sciences, \\ Favorskogo 1A, Irkutsk, 664033, Russia \\ E-mail:kaneva@igc.irk.ru \\ ${ }^{4}$ Université Côte d'Azur, \\ CNRS UMR 7264 CEPAM, Nice, France \\ E-mail: aureade.henry@cepam.cnrs.fr; \\ eugenie.gauvrit-roux@cepam.cnrs.fr
}

\title{
Ocher in Late Paleolithic Contexts at the Kovrizhka IV Site, the Baikal-Patom Highlands (Eastern Siberia, Russia)
}

This paper deals with numerous ocher remains found in cultural layers $6,2 G$, and $2 B$ of the Paleolithic site Kovrizhka IV on the Vitim River, in the Baikal-Patom Highlands (Eastern Siberia). These layers are dated by radiocarbon to the interval of $\sim 19.2-18.3 \mathrm{ka}$ cal $B P$. In cultural layers $2 B$ and $2 G$, ocher colored the living floors and combustion areas. Stratigraphic observations indicate that this was done at the very beginning of the occupation. In layer 6, traces of ocher were present on an anthropomorphic figurine made of mammoth ivory, and pieces of ocher were found near the head of another such figurine. In layer 2B, a large piece of ocher was unearthed at the edge of the hearth. Ocher residues were also detected by use-wear analysis on certain artifacts. This variety of patterns suggests different functions of ocher, possibly both symbolic and utilitarian. The mineral composition of ocher was assessed by X-ray diffraction analysis. In all three layers, hematite is associated with quartz. In layer $2 G$, an additional type of ocher was identified, containing impurities, such as calcite and chlorite. Known sources of ocher are located in the distribution areas of magnetite and hematite ores, over $500 \mathrm{~km}$ southwest and southeast of Kovrizhka IV. The importance of ocher in the life of these societies is discussed in light of the archaeological evidence and the longdistance raw material acquisition patterns of ocher.

Keywords: Late Paleolithic, Eastern Siberia, Kovrizhka IV, dwelling, ocher, hematite.

Archaeology, Ethnology \& Anthropology of Eurasia 48/3 (2020) 33-42 E-mail: Eurasia@archaeology.nsc.ru (C) 2020 Siberian Branch of the Russian Academy of Sciences

(c) 2020 Institute of Archaeology and Ethnography of the Siberian Branch of the Russian Academy of Sciences (C) 2020 A.V. Tetenkin, E.I. Demonterova, E.V. Kaneva, A. Henry, E. Gauvrit Roux 


\section{Introduction}

The use of pigments by prehistoric societies is one of the key themes of Paleolithic studies in Eastern Europe and Northern Asia. This subject traditionally attracts attention because it is usually related to the symbolic behavior of anatomically modern humans. The use of different types of pigments, traditionally referred to in the literature as "ocher", has been reported from various Late Paleolithic sites in Siberia, within different sedimentary contexts. More specifically, the use of ocher for coloring various items, such as personal ornaments, was reported at the sites of Kara-Bom and Maloyalomanskaya in the Altai Mountains; and at Podzvonkaya, Kamenka A, Khotyk, and Varvarina Gora in Transbaikalia (Derevianko, Rybin, 2003: 44-46). A pendant pigmented with ocher, dated around $43 \mathrm{ka} \mathrm{BP}$, was found at Kara-Bom, layer 5 (Ibid.: 38-41). In northern Siberia, the oldest artifacts pigmented with ocher (ca $32 \mathrm{ka} \mathrm{BP}$ ) were found at the Yana site, where locally made beads were pigmented with ocher mixed with fat (Pitulko et al., 2012). The researchers hypothesized that this mixture was also used as a repellent for blood-sucking insects (Ibid.: 82). Ocher remains were also found at Shestakovo (layer 6, which yielded an anthropomorphic figurine) in Western Siberia (Derevianko et al., 2003: Fig. 46); Listvenka (as isolated ocher residues in layer 16) and Uy II (layer 7) in the Yenisey Region; and Malaya Syya, Khakassia (Paleolit..., 2005: 114-115; Vasiliev, 1996: 187; Lbova, Kulik, Gubar, 2018). Coloring substances in the form of isolated lumps and pigment residues on figurines were reported at Malta (Gerasimov, 1931, 1958; Lbova, 2018). Ocher was also recorded in layer III (ca 17.8 ka BP) of Malta-Most-1, CisBaikal (Berdnikova, Vorobieva, 1995: 92). The authors reported that pigments were spread over the living floor right before the occupants left the site. Lumps and isolated spots of ocher were noted on stones at the settlements of Ust-Kyakhta-17 (layers 3 and 5), Ust-Menza-3 (layer 4), and Studenoye-1 (layers 11 and 19/4) (Tashak, 2005: 32, 35-37; Konstantinov, 1994: 75, 79, 91). Evidences of the use of ocher were noted at the sites of Ushki I-V in Kamchatka: the excavations yielded a fish geoglyph made of ocher, and dwelling floors, graves, and human burials powdered with ocher (Dikov, 1993: 10-11, 24, 25, 32). In Eastern Beringia, ocher was also found in a burial dated ca 11.5 ka BP (Upward Sun River) in Alaska (Potter et al., 2014).

Occurrences of ocher and other coloring agents are mostly interpreted as being related with ritual or symbolic behaviors; however, some scholars associate them with utilitarian purposes (Delibes de Castro, 2000; Domingo, Garcia-Borja, Roldan, 2012; Pradeau et al., 2014; Usacheva et al., 2018). Of course, interpretations largely depend on the archaeological context of the discoveries. Here, we present the various contexts that yielded ocher within the Late Paleolithic layers of Kovrizhka IV, on the lower part of the Vitim River. Judging by the quantity of ocher remains at the site, it likely played an important role in the life of people in this area about 19-18 ka BP (hereafter, all radiocarbon dates are given in ka cal BP).

Kovrizhka IV is located in the central part of the Baikal-Patom Highlands, in the North-Baikal region, at the northeastern tip of the Irkutsk Region (Fig. 1) (Tetenkin, Henry, Klementiev, 2017). It is located on an 11-m-high terrace, on the right bank of the Vitim River. To date, 16 layers have been identified at the site. 14 of them are embedded in flood-plain alluvium fascia. Layers $6,2 \mathrm{G}$, and $2 \mathrm{~B}$ are the most studied to date. The first analysis of the pigments of these layers (2012-2018) showed a broad use of ocher. In an earlier publication, we presented the results of the X-ray diffraction analysis of the ocher pieces, indicating that the coloring agent was hematite. Reinforcing available regional data, our results suggest that the use of ocher was a wide-spread Paleolithic tradition (Tetenkin et al., 2018). This paper focuses more specifically on the socio-economical aspect of ocher use. For layers 6, 2G and 2B, we present in detail the contexts in which ocher was found, as well as the results of new analyses of the mineral composition of the substances used. Furthermore, analyses of minerals associated with the ocher remains from different layers at Kovrizhka IV allowed evidencing potential raw material sources (i.e., iron ores located in the Northern Transbaikalia).

\section{Complex of layer 6}

This complex includes remains of a dwelling about $4.5 \mathrm{~m}$ in diameter, structured by two hearths and delimited by a semi-circular line of 12 boulders and slabs in the western margin of the residential area; one hearth is located at the radial center, the other one at its end, which may correspond to the dwelling entrance (Fig. 2,a). Several AMS-dates were obtained: 15,558 $\pm 103 \mathrm{BP}$ (Ua50437 ) on bone, and 15,740 \pm 100 (LTL-16562A) and $15,750 \pm 60$ BP (Beta-453119) on charcoal. Calibration, based on the two last-mentioned dates, provides the interval of 19.2-18.8 ka BP (after (Bronk Ramsey, 2017; Reimer et al., 2013)). Two artifacts made from mammoth ivory, interpreted as anthropomorphic figurines, were unearthed within this complex and restored (Tetenkin, Henry, Klementiev, 2017; Tetenkin et al., 2018).

The ocher pieces and pale pink coloration are associated with artifact concentrations within the dwelling limits and at the entrance of the household zone (Fig. 2,a). Ocher is one of the four main categories of cultural remains, along with knapped lithic industry, charcoal and bone fragments. Use-wear analysis made using microscopes MFU MBS-10 (×4.8-×98), Olympus 


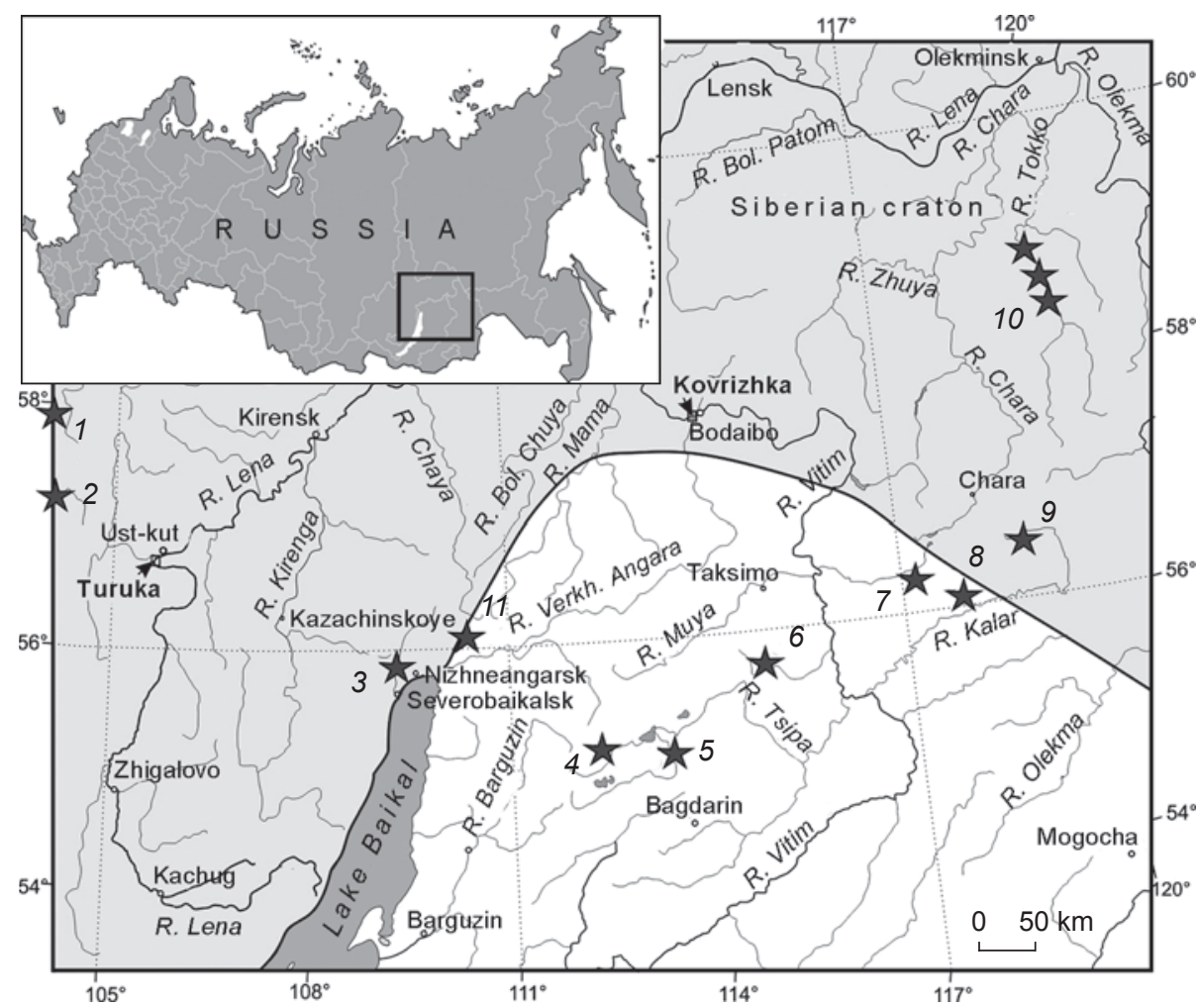

Fig. 1. Location of the Kovrizhka IV site, Turuka cemetery, and iron-ore deposits in the region. 1 - Rudnogorsk; 2 - Korshunovsky; 3 - Tyya group; 4 - Toldun; 5 - Taloy; 6 - Irokinda; 7 - Nizhny Ingamakit; 8 - Katugin; 9 - Chiney; 10 - Chara-Tokko group; 11 - Abchada group.

BH2-UMA $(\times 100-\times 200)$, and Dino-Lite Digital Microscope Premier $(\times 30-\times 250)$ showed occurrences of ocher on the surfaces of some artifacts. One of two retouched tools, typologically identified as a side-scraper and used as a knife, bears microscopic traces of ocher on the proximal part of its face, in a retouched and thinned area (Fig. 3,e). One of the anthropomorphic figurines, found in the southeastern part of the dwelling, showed vivid traces of ocher on its head (Fig. 3,a). In the course of restoration, ocher was also noted on the figurine on its lower surface (Fig. 3, b). Some pieces of ocher were also found close to the head of the second anthropomorphic figurine unearthed in the entrance area (Fig. 3,c) (Tetenkin et al. 2018).
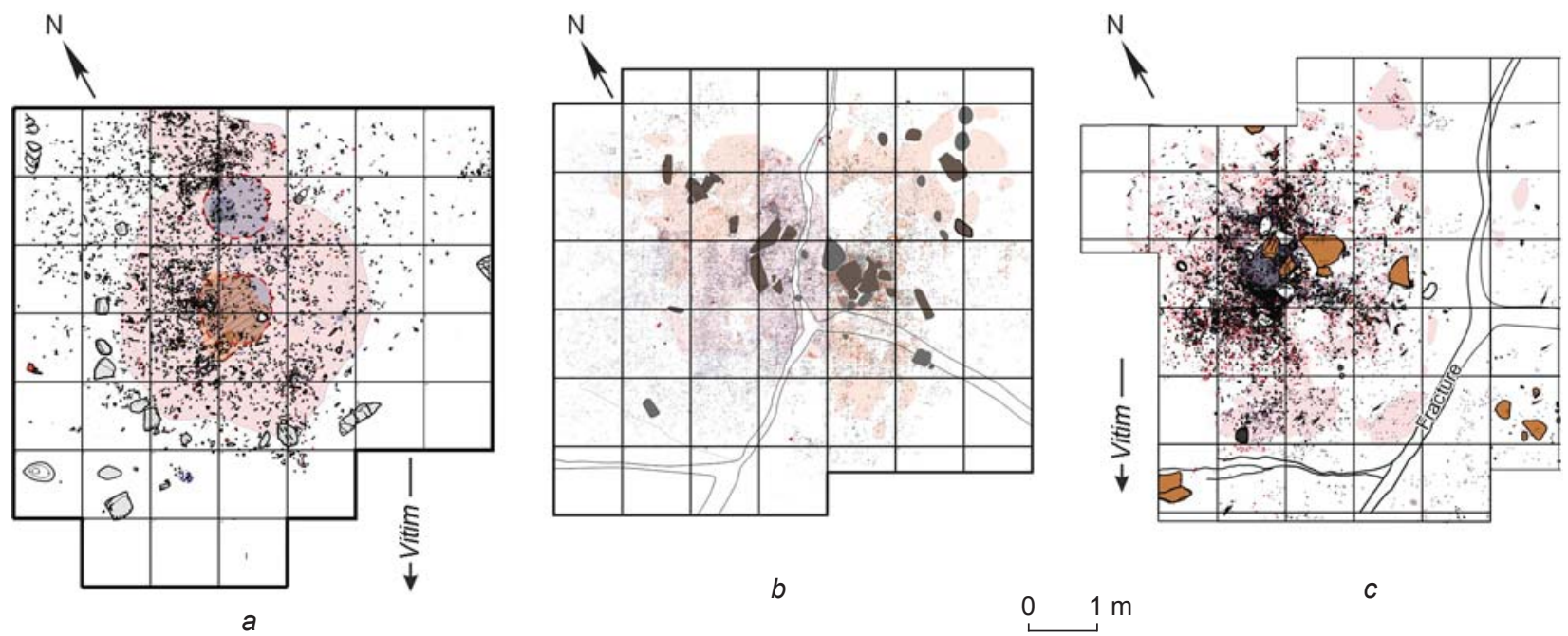

$b$

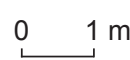

c

Fig. 2. Planigraphy of the complexes of layers $6(a), 2 \mathrm{G}(b)$, and $2 \mathrm{~B}(c)$. 

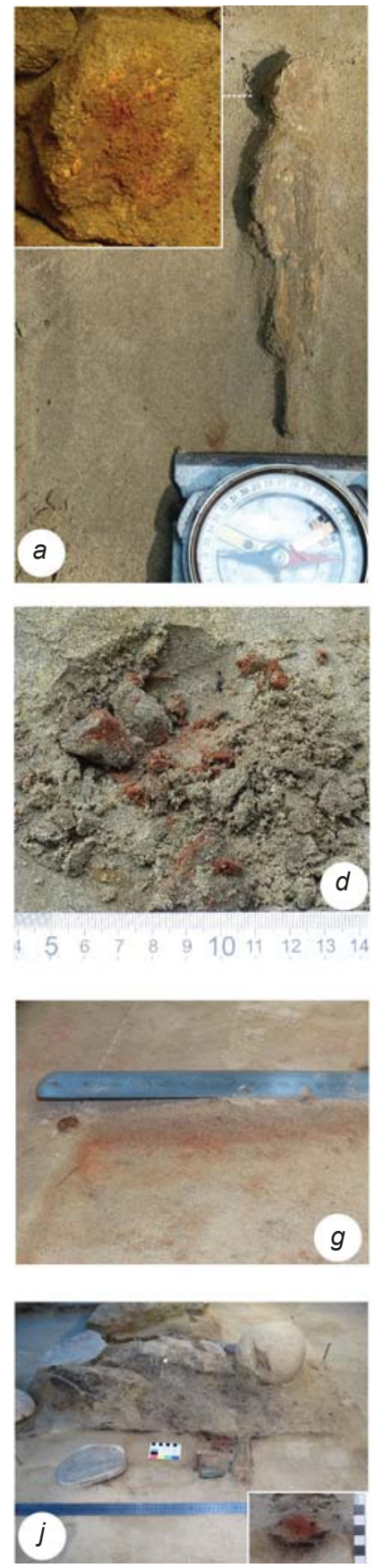
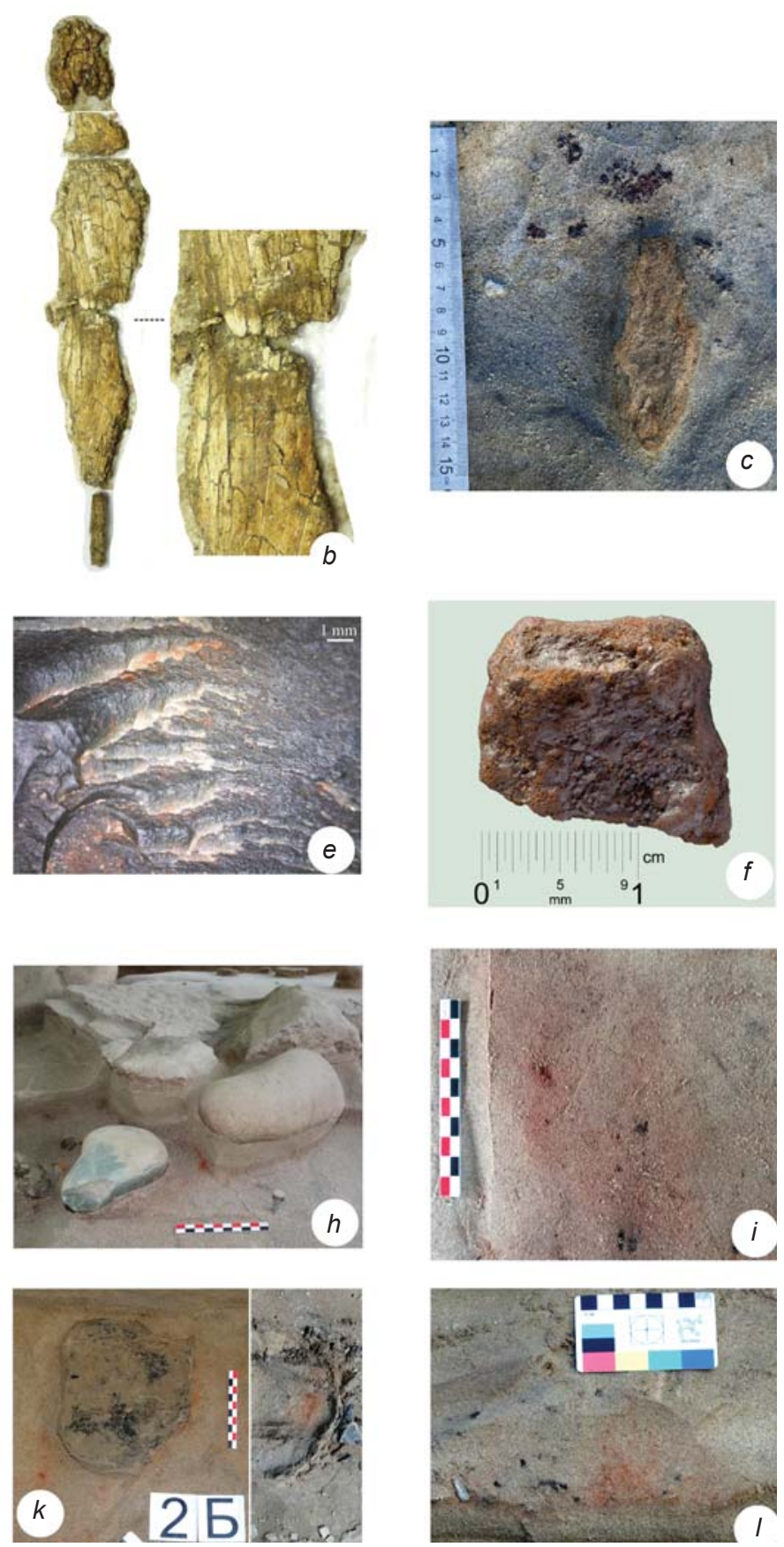

Fig. 3. Ocher among other cultural artifacts from layers $6(a-d), 2 \mathrm{G}(f-i)$, and $2 \mathrm{~B}(j-l)$.

$a$ - the first anthropomorphic mammoth ivory figurine in layer 6 in the course of discovery; ocher traces on the "head"; $b-$ same figurine during restoration: ocher traces on the lower surface (photo by O.V. Zhmur); $c$ - the second anthropomorphic mammoth ivory figurine in layer 6 in the course of discovery: ocher pieces close to the "head"; $d$ - decomposed ocher piece; $e$-ocher traces on the ventral surface of a knife; $f$-hematite piece with rounded edges; $g$-ocher at the bottom of the cultural layer; $h$-ocher below the hearth construction; $i, k, l$-ocher coloration of layer; $j$-ocher piece next to a split tubular bone at the western margin of hearth.

\section{Complex of layer 2G}

Several AMS-dates on charcoal are available for layer 2G: $15,320 \pm 80 \mathrm{BP}$ (Poz-111356), 15,360 $\pm 110 \mathrm{BP}$ (Poz-111232); the underlying layer 2D was dated to
$15,350 \pm 150$ BP (Poz-106968). The calibrated interval of layer $2 \mathrm{G}$ is ca $18.8-18.4 \mathrm{ka}$ BP. The complex includes: 1) the base of the living floor, colored with ocher; 2) hearth with charcoal fragments disseminated over an area of ca $5 \mathrm{~m}^{2} ; 3$ ) four stone slabs, forming a half circle 
at the center of the combustion area, and a thick flat slab outlined with a large boulder and fragments of gneiss at the opposite ends; 4) alignment of four stones, as well as two isolated rock fragments, in the northern and northwestern sectors; 5) two pits $20 \mathrm{~cm}$ in diameter (one up to $7 \mathrm{~cm}$ deep, the other up to $2 \mathrm{~cm}$ deep) at the northern and southern edges of the complex; 6) slabs and boulders forming a contour of an arch-shaped pattern of 11 stones at the eastern periphery of the area, and isolated stones in the northern and western sectors (see Fig. 2, b). Most of the debitage and all the tools are located in the center and in the northwestern part of the hearth, whereas the faunal remains are scattered towards the southeast. A significant feature is the reddish coloration of the whole area at the very base of the occupation layer (see Fig. 3, g). Traces of ocher are also noted below the combustion area (see Fig. $3, h)$. The largest piece of hematite bears signs of abrasion at its edges (see Fig. 3, f). The complex is interpreted as the remains of a dwelling.

\section{Hearth complex of layer 2B}

The hearth complex with adjacent cultural remains occupies an area of about $4.5 \times 4.5 \mathrm{~m}$ (see Fig. 2, c) (Tetenkin, 2019). Several AMS-dates are available for layer 2B: 15,320 $\pm 100 \mathrm{BP}$ (LTL-16563A) and 15,460 \pm $\pm 80 \mathrm{BP}$ (Poz-106962) on charcoal, and 14,940 $\pm 80 \mathrm{BP}$ (Poz-106023) on bone. The interval of ca 18.8$18.3 \mathrm{ka} \mathrm{BP}$ was generated from the first-mentioned date, which is well-correlated with the datings from layers $2 \mathrm{G}$ and $2 \mathrm{D}$. Unlike layers 6 and $2 \mathrm{G}$, where no cultural remains are noted outside the described complexes, layer $2 \mathrm{~B}$ proves to be a rather large cultural layer, in which the hearth complex is only one of the structural components.

Six boulders and slabs are located over the charcoal concentrations in the eastern half of the combustion area, which measures $0.90 \times 0.65 \mathrm{~m}$. The stone artifacts are located mostly in the northeastern, northern, and northwestern margins of the hearth. Almost all the large bones were found south of the hearth, including two mandibles of bighorn sheep. A very intriguing find consisted of a disc of black, packed, consolidated, terrigenous, fine-grained sediment-like aleurite (silt), $12 \mathrm{~cm}$ in diameter and $2 \mathrm{~cm}$ thick, located $0.35 \mathrm{~m}$ north of the hearth. The X-ray fluorescence analysis shows that the chemical composition of this feature is identical to the black aleurite (silt) from the piled material over the hearth at the center of the dwelling in layer 6 (Tetenkin et al., 2018: 10).

The area surrounding the hearth is strongly colored with ocher. The majority of the finds are located on top of the cultural layer, again colored with ocher (see Fig. 2, $c$; $3, k, l)$. This is the reason why most of the lower surfaces of the artifacts bear traces of ocher. In some cases, traces of ocher result from the dissolution of ocher fragments over time. There are areas with continuous strong red coloration, where ocher lumps are quite rare, and artifacts show ocher residues on their surface. Areas completely free of ocher coloration and cultural remains are located at the northern edge of the combustion structure and at the southern edge of the dwelling behind the hearth (see Fig. 2,c). These areas probably correspond to previous positions of the gneiss slab $(63 \times 45 \mathrm{~cm})$ and of the boulder $(30 \times 40 \mathrm{~cm})$, northeast of the fireplace.

Ocher is absent from the center of the hearth. At its northwestern edge, free of stone pavement, there is a 15-cm-long tubular bone split lengthwise and a brightcolored stain $6 \mathrm{~cm}$ in diameter-a disintegrated ocher lump (see Fig. 3, $j$ ).

\section{Ocher composition}

The first results of the analysis of ocher from Kovrizhka show that the pigmenting mineral is hematite $\left(\alpha-\mathrm{Fe}_{2} \mathrm{O}_{3}\right)$ (Tetenkin et al., 2018). The analysis of 19 new samples from layers described above (Table 1) shows that their mineral composition is not homogenous. The powder $\mathrm{X}$-ray diffraction method shows that the proportions of hematite in the ocher found at Kovrizhka IV vary from $21 \%$ to $96 \%$ and those of quartz from $4 \%$ to $64 \%$ (Fig. 4). Accessory minerals are scarce and include mica (muscovite), feldspar, goethite, chlorite, and more rarely calcite, fluorapatite, and cordierite. All three layers yield pieces of ocher composed of the quartz-hematite association. They often show spherical grains of hematite in the form of oolites and rounded quartz particles (see Fig. $3, f)$. This type is more typical of layers $2 \mathrm{~B}$ and 6 . Unlike the latter, layer $2 \mathrm{G}$ yields pieces of ocher with higher shares of accessory minerals, such as calcite and chlorite, up to $12 \%$.

\section{Discussion}

In layer 6 , unlike layers $2 \mathrm{~B}$ and $2 \mathrm{G}$, the inner dwelling area and the entrance zone do not show strong coloration with ocher. A pale pink coloration was however noted in the course of the excavation of the cultural layer $(1 \mathrm{~cm}$ thick on average). With this very residual evidence, we can thus only assume the presence of a colored living floor, on the basis of the evidence from layers $2 \mathrm{~B}$ and $2 \mathrm{G}$. Additional evidence for the spread of powdered ocher over the living floor is provided by the microscopic traces observed on the lower sides of the artifacts surfaces. On the other hand, traces of ocher on the ventral surface of a knife (see Fig. 3,e) may represent the remains of a compound that fastened the handle. Alternatively, the 
Table 1. Mineral composition of ocher from Kovrizhka IV, \%

\begin{tabular}{|c|c|c|c|c|c|c|c|c|}
\hline Sampling point & Hematite & Quartz & Mica & Feldspar & Goethite & Chlorite & Fluorapatite & Calcite \\
\hline \multicolumn{9}{|c|}{ Horizon $2 B$} \\
\hline Unit 44 , sq. $12^{*}$ & 72 & 28 & - & - & - & - & - & - \\
\hline Same, sq. 6* & 89 & 11 & - & - & - & - & - & - \\
\hline Same, sq. 18 , qtr. $3 *$ & 21 & 32 & & 47 & - & - & - & - \\
\hline Same, sq. 13 , qtr. $1^{*}$ & 42 & - & - & - & 58 & - & - & - \\
\hline Test pit $14^{*}$ & 45 & 44 & - & - & 11 & - & - & - \\
\hline Unit 44, sq. 12 & 92 & 8 & - & - & - & - & - & - \\
\hline \multicolumn{9}{|c|}{ Horizon 2G } \\
\hline Same, sq. 17 & 36 & 28 & 23 & - & - & 13 & - & - \\
\hline Same, sq. 21 & 36 & 28 & 22 & - & - & 14 & - & - \\
\hline Same, sq. 23, qtr. 2 & 64 & 20 & - & - & - & - & 16 & - \\
\hline Same, sq. 24 & 75 & 25 & - & - & - & - & - & - \\
\hline$"$ & 29 & 64 & - & - & - & 7 & - & - \\
\hline Unit 48 , sq. 23 , qtr. 1 & 51 & 49 & - & - & - & - & - & - \\
\hline Same, sq. 2 , qtr. 1 & 17 & 51 & 4 & 10 & - & 6 & - & 12 \\
\hline Same, sq. 1 & 60 & 40 & - & - & - & - & - & - \\
\hline$"$ & 65 & 35 & - & - & - & - & - & - \\
\hline \multicolumn{9}{|c|}{ Horizon 6} \\
\hline Unit 40 , sq. $4^{*}$ & 96 & 4 & - & - & - & - & - & - \\
\hline Unit 36 , sq. $23^{*}$ & 58 & 42 & - & - & - & - & - & - \\
\hline Same, sq. 19, qtr. $4 *$ & 97 & 29 & 4 & - & - & - & - & - \\
\hline Same, sq. 12 & 85 & 15 & - & - & - & - & - & - \\
\hline
\end{tabular}

Notes: The mineral composition of ocher was assessed by powder X-ray diffraction analysis in diffractometer D8 ADVANCE Bruker, with Göbel mirror and VÅNTEC-1 PSD detector. The obtained data were processed with DIFFRACplus program package. Mineral phases in the samples were identified using the powder diffraction file database PDF-2 (https: //www.icdol.com/index.php/ pdf-2) and EVA program (https: //www.bruker.com/products/x-ray-diffraction-and-elemental-analysis-X-ray-diffraction/xrd-software/ eva.html).

*The data are after (Tetenkin et al., 2018).

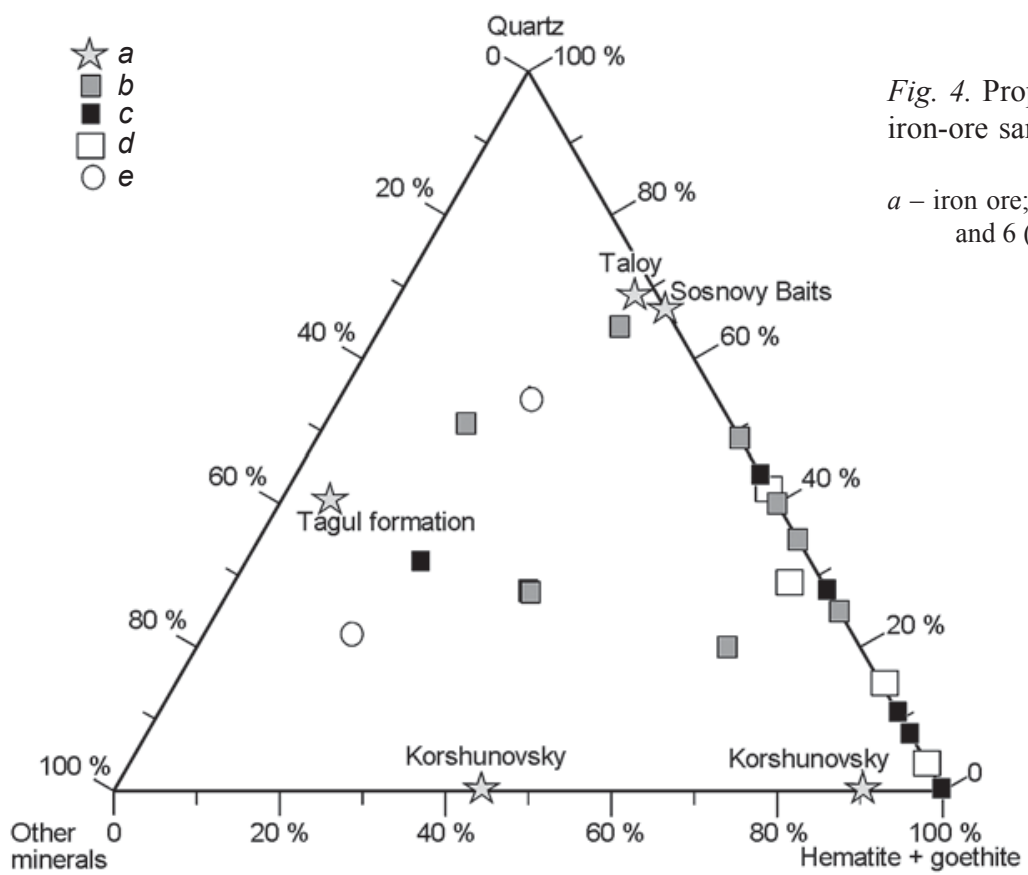


randomly dispersed microstains on this and other artifacts could be accidental.

The ocher traces on the lower surface of the figurine (i.e. on the body) found in the dwelling of layer 6 may be the natural result of its burial in a colored soil (see Fig. 3, $b$ ). However, the upper part of its "head" shows clear traces of ocher (Fig. 3, $a$ ), and a few lumps were found near the head of the second figurine (see Fig. 3, c). Neither case seems accidental.

In addition to a specific behavior linked to ocher, the case of the black aleurite (silt) supports the hypothesis of a cultural continuity between layers 6 and 2B. This matter was found in the hearth of layer 6 and close to the combustion structure of layer 2B. The extremely regular shape of the deposit, a $12 \mathrm{~cm}$-large and $2 \mathrm{~cm}$ thick disc, suggests it was initially placed in some container. Its composition turned out to be identical to the black aleurite (silt) sediment overlying the central hearth of layer 6 . Thus, it appears that recurrent gestures may have consisted of spreading red ocher powder over the living floor upon the arrival of humans, and of filling the hearth with black sediment before the abandonment of the dwelling. It is unclear to what extent this succession of events is connected within a technological or ritual context. The excavation area of layer $2 \mathrm{G}$ is entirely covered with ocher. It is clearly visible at the bottom of the cultural layer and below all the main structural elements-combustion and living floor areas (see Fig. $3, g, h)$. The ocher traces at the northeastern edge of the northern hearth pavement are particularly brightcolored (see Fig. 2, b). At the opposite side of the hearth, there is an area $0.60 \mathrm{~m}$ wide almost devoid of ocher. A possible explanation could be that this area was covered while the powder was scattered, maybe by a mat of some sort. The ocher spot at the southeastern part extends beyond the slabs and boulders; hematite seems to have been scattered before the dwelling was built (i.e., before the stones were placed) on the already colored ground.

The situation in layer 2B is partially similar; the only difference is that the hearth area is not colored; only small pieces of ocher were recorded, in addition to a large decomposed lump of ocher found next to the fractured bone at the western edge of the hearth (see Fig. 3, j). It can be proposed that these two items were intentionally left next to the hearth at the end of the occupation period.

The piece of ocher $(1.5 \mathrm{~cm}$ long) found in layer $2 \mathrm{G}$, shows rounded edges in cross-section (see Fig. $3, f$ ). This may be the result of either transport or abrasion. No signs of destruction or dissolution of the pigment were noted in the layer, near the place where this item was found. Moreover, given the relatively calm conditions of the formation of the layer, i.e., fine alluvial deposits, we exclude the hypothesis of a natural abrasion of the item in the course of the formation of the cultural horizon in favor of a modification of anthropogenic origin.
Archaeological studies of ocher and ethnographic data report very different possible uses of this material, among which as a dye for certain categories of items, as an antiseptic or protective agent against decay, or as an element used in hide-processing (Pomies, Menu, Vignaud, 1999; Domingo, Garcia-Borja, Roldan, 2012; Pradeau et al., 2014; Delibes de Castro, 2000). However, hideprocessing tools were not identified among the lithic artifacts from layer 2B studied by the use-wear analyst J. Jacquier. Some tools of this layer were used on mineral materials, yet ocher particles are not recorded on the used areas of these tools. Several tools from layer 6 were used for hide-scraping, but ocher residues are also absent from the used areas. In the absence of further evidence, it is difficult to support the hypothesis of the use of ocher for hide-processing at Kovrizhka.

Zooarchaeological analyses tend to show that all three complexes were occupied in winter. Considering that the dwellings may have consisted of wooden structures and other perishable materials, ocher could also have been used for "protecting wooden constructions from decay and keeping a dry atmosphere inside the dwelling"; such explanation is proposed in the interpretation of the Mesolithic-Chalcolithic dwellings in Trans-Urals and northwestern Siberia (Usacheva et al., 2018: 257); see also (Delibes de Castro, 2000). However, only charred wood is preserved, and no traces of special treatment with ocher were found in the pits probably left from posts supporting dwelling constructions (layers 6 and 2B).

Layers $2 \mathrm{~B}$ and $2 \mathrm{G}$ are chronologically, stratigraphically, and spatially close to one another, with the combustion feature of $2 \mathrm{~B}$ located exactly above the hearth of $2 \mathrm{G}$. These two structures are separated by a layer of sterile sand and by layer $2 \mathrm{~V}$, which contained few finds, the total thickness of both being about $8 \mathrm{~cm}$. One of the boulders from layer $2 \mathrm{~B}$ lays almost on top of a hearth slab of layer $2 \mathrm{G}$; three other cases of contacts between the slabs from these layers are noted. The calendar ages determined on charcoal are ca $18,576 \mathrm{cal} \mathrm{BP}$ for $2 \mathrm{~B}$, and ca $18,574-18,583 \mathrm{cal} \mathrm{BP}$ for $2 \mathrm{G}$, which are well-correlated with the date of ca 18,600 cal BP for the cultural layer 2D. The available dates suggest that the gap between these occupation episodes did not exceed the life-span of one human generation. Apparently, the occupants of layer 2B, who treated the area with ocher, were aware that they had arrived in a previously inhabited place. The same inference is true for layer $2 \mathrm{G}$, directly overlying layer $2 \mathrm{D}$. Was the spreading of ocher powder at the beginning of each occupation a tradition (of utilitarian or symbolical nature) that was performed in order to "clean" the living area? Was this related to the fact that people settled previously inhabited places? In the current state of our knowledge, it seems difficult to explain these gestures further. However, they had to be of extreme relevance considering the remote provenience of the ocher used at the site. 
Hematite, the coloring mineral composing the ocher used at Kovrizhka IV, is very common in ironore deposits. There are dozens of iron-ore deposits in Eastern Siberia (Zhelezorudniye mestorozhdeniya..., 1981: 14-21). These ores are of various ages and mineral associations, which can be used to trace the origin of the ore. Thus, the analysis of the ocher's mineral composition makes it possible to establish its provenance. There are no iron-ore deposits in the lower part of the Vitim Basin (see Fig. 1). The X-ray phase analysis of the ferruginous gneiss sampled from the outcrops in the vicinity of the site does not show the presence of hematite. Yet, the sources of Kovrizhka IV ocher are magnetite and hematite ores (Table 2). The more frequent occurrences of iron ores are associated with Precambrian sedimentary rocks, i.e. ferruginous quartzites occurring in the Siberian Craton (see Fig. 1). Such deposits of various genesis formed in the upper tributaries of the Vitim River, in the northern part of Lake Baikal, in the Upper Chara River, and its right-side tributary Tokko.

On the basis of the mineral association, at least two distinct types of ocher can be identified. The first one is the quartz-hematite association with minor admixtures of mica and feldspar, of the oolitic texture. This type of ocher (see Fig. 3, $f$ ) was recorded in all layers discussed here. The oolitic texture of hematite, characterized by spherical grains, was observed at the Taloy ore field (the Upper Vitim River, Taloy and Usoy interfluve), and also at the fields of the Angara-Ilimsky District (the Irkutsk Region) and of the Chara-Tokko group. The latter contain oolitic ores devoid of quartz, occurring in association with chlorite and calcite (Zhelezorudniye mestorozhdeniya..., 1953: 16-20, 70; Rudniye mestorozhdeniya..., 1978: 71; Charo-Tokkinskaya... formatsiya, 1984: 8, 86). Thus, the ores from the Taloy and Chara-Tokko ore fields can be regarded as the probable sources for the first type of ocher.

The second type of ocher is recorded only in layer $2 \mathrm{G}$. This type has a wider mineral composition: besides quartz and hematite, it contains chlorite, various micas, feldspar and calcite. This mineral association is typical of skarn deposits, known in the Angara-Ilimsky and SeveroBaikalsky districts (see Fig. 1). Two ocher samples from the Neolithic cemetery of Turuka (near the town of Ust-Kut, on the Lena River; see Fig. 1) were taken for comparative analysis. These samples show the presence of hematite (17\% and $23 \%$ ), quartz ( $22 \%$ and $54 \%$ ), mica (5\% in each), feldspar ( $40 \%$ and $6 \%$ ), chlorite (3\% and $4 \%$ ), calcite (5\% in each); sample 1 also contains cordierite ( $5 \%$ ). A similar mineral association is observed in several samples of ocher type 2 from layer $2 \mathrm{G}$. Given the age of this layer (18 ka), it should be taken into account that during MIS 2, mountains and valleys in the southern part of the Baikal-Patom Highlands were covered with glaciers. As the Lena-Angara-Ilim region is connected with Kovrizhka by a single river-system, it seems the most probable origin for the ocher found at the site.

Judging by the abovementioned facts, we can assume that hematite was transported to the site from various regions of the eastern (southeastern) or western (southwestern) direction, located at a distance of no more than $500 \mathrm{~km}$.

Currently, the phenomenon of processing living floors with ocher in the Vitim valley is known only for the period of 19.3-18.2 ka BP. So far, Kovrizhka IV layers 6, 2G, and $2 \mathrm{~B}$ are the oldest occupation layers containing ocher in the region. The excavated hearth complexes from layers 9,8 , 7, 6, 5, 4V, 4B, 4A, 4, 3V, 3B at Bolshoy Yakor I (15.013.6 ka BP); 8a, 8, 7 at Ust-Karenga (15.4-12.7 ka BP), and layer 2 of Kovrizhka III (13.0-12.2 ka BP) do not yield anything of the kind. Layer 4A at Bolshoy Yakor I contained a piece of rock bearing traces of ocher grinding; layer 2 at Kovrizhka IV (13.5-13.1 ka BP) yielded a pebble with similar signs and vague ocher spots within the sedimentary matrix. Layer 4A at Kovrizhka II (9.2 ka BP) yielded small solitary traces of ocher. Considerably large amounts of ocher were only recorded at the cemetery of Stary Vitim II and at the site of Ust-Karenga XVI at the bottom of graves and ritual pits, respectively (Vetrov, 2008). These sites were dated to 8-7 ka BP; i.e., over 9000 years younger than layers $6,2 \mathrm{~B}$, and $2 \mathrm{G}$ of Kovrizhka IV. In the Cis-Baikal region, in that time, i.e. Final Mesolithic to Early Neolithic transition, ocher was recorded in the burials of Shchukino and Ershi cemeteries, as well as in the Kitoy culture burials (Bazaliysky, 2012).

Table 2. Mineral composition of iron ores

\begin{tabular}{|l|c|c|c|c|c|c|c|}
\hline \multicolumn{1}{|c|}{ Sampling point } & Hematite & Quartz & Mica & Feldspar & Chlorite & Calcite & Magnetite \\
\hline Taloy & 28 & 69 & - & 3 & - & - & - \\
Sosnovy Baits & 33 & 67 & - & - & - & - & - \\
Korshunovsky, sample 1 & 18 & - & - & - & 22 & 34 & 26 \\
Same, sample 2 & - & - & - & - & - & 10 & 90 \\
Tagul formation & 6 & 40 & 9 & 30 & 15 & - \\
\hline
\end{tabular}




\section{Conclusion}

We evidenced the earliest use of ocher known so far in the lower part of the Vitim Basin (19.3-18.2 ka BP), within three chronologically close complexes from layers 6 , $2 \mathrm{G}$, and $2 \mathrm{~B}$ at Kovrizhka IV. Analysis of ocher and its mineral sources was carried out along with studies of other cultural aspects. The general context of the site was the decisive factor in the perception and interpretation of the coloration of the cultural layer and artifacts by ocher.

Indeed, far from representing isolated spots or fragments, ocher is found dispersed over the entire occupational areas, i.e. living floors, and combustion features, black aleurite (silt) being found associated to the latter in some instances. Ocher was also found on artifacts, such as anthropomorphic ivory figurines and stone tools. The purpose of these procedures may have been ritual, utilitarian, or both. In some cases, the coloring of the items may have been due to the random contacts with ocher on the layer or during the transportation.

The main mineral composing the ocher was hematite, which was prepared by crushing and grinding rocks with high hematite content (up to $94 \%$ ). Hematite was transported over long distances from deposits located at a minimum of $500 \mathrm{~km}$. Ocher from layer $2 \mathrm{G}$ was transported from other deposits, possibly from the west and/or east (i.e. the Lena Basin).

\section{Acknowledgements}

Archaeological studies were supported by the Russian Foundation for Basic Research (Project No. 18-59-22003\18). Analytical works were supported by the Russian Science Foundation (Project No. 19-78-10084) in the Center for Collective Use "Geodynamics and Geochronology" of the Institute of Geochemistry SB RAS. Colleagues from France were supported by Maison Fondation Sciences de l'Homme, in the frame of the project "LicHENS" Late Pleistocene HunterGatherer Adaptations to Tundra Environments in North-Baikal Siberia".

The authors thank V.I. Bazaliysky (Irkutsk State University) for submitting the ocher samples from the burial of Turuka; and O.V. Zhmur (Peter the Great Museum of Anthropology and Ethnography (Kunstkamera) RAS) for the assistance in the study of the ivory figurines. Special thanks go to V.I. Levitsky (Sosnovy Baits iron ore deposit), S.I. Shkolnik (Taloy, Tagul formation), and T.A. Radomskaya (Korshunovsky iron ore deposit) for submitting the ore samples from the deposits.

References

\section{Bazaliysky V.I. 2012}

Pogrebalniye kompleksy epokhi pozdnego mezolita - neolita Baikalskoy Sibiri: Traditsii pogrebeniy, absolyutniy vozrast. Izvestiya Laboratorii drevnikh tekhnologiy, iss. 9: 43-101.

\section{Berdnikova N.E., Vorobieva G.A. 1995}

Novoye mestonakhozhdeniye Malta-Most-1 (Pribaikalye, r. Belaya): Paleoekologicheskiy aspekt $\mathrm{v}$ issledovanii. In Prirodniye resursy, ekologiya i sotsialnaya sreda Pribaikalya, vol. 3. Irkutsk: Izd. Irkut. Gos. Univ., pp. 89-93.

\section{Bronk Ramsey C. 2017}

Methods for summarizing radiocarbon datasets. Radiocarbon, vol. 59 (2): 1809-1813.

\section{Charo-Tokkinskaya kremnisto-zhelezorudnaya}

formatsiya. 1984

V.A. Kuznetsov (ed.). Novosibirsk: Nauka. (Trudy Inst. Geologii i Geofiziki; iss. 594).

Delibes de Castro G. 2000

Cinabrio, huesos pintados en rojo y tumbas de ocre: Prácticas de embalsamamiento en la Prehistoria? In Scripta in honorem Enrique A. Llobregat Conesa, M. Olcina, J. Soler (eds.), vol. 1. Alicante: Instituto Alicantino de Cultural Juan Gil. Albert, pp. 223-236.

Derevianko A.P., Molodin V.N., Zenin V.N.,

Leshchinsky S.V., Mashchenko E.N. 2003

Pozdnepaleoliticheskoye mestonakhozhdeniye Shestakovo. Novosibirsk: Izd. IAET SO RAN.

\section{Derevianko A.P., Rybin E.P. 2003}

The earliest representations of symbolic behavior by Paleolithic humans in the Altai Mountains. Archaeology, Ethnology and Anthropology of Eurasia, No. 3: 27-50.

Dikov N.N. 1993

Paleolit Kamchatki i Chukotki v svyazi s problemoy pervonachalnogo zaseleniya Ameriki. Magadan: SVKNII DVO RAN.

Domingo I., Garcia-Borja P., Roldan C. 2012

Identification, processing and use of red pigments (hematite and cinnabar) in the Valencian Early Neolithic (Spain). Archaeometry, vol. 54 (5): 868-892.

Gerasimov M.M. 1931

Paleoliticheskaya stoyanka v Malte. Soobscheniya GAIMK, No. 11/12: 55-57.

\section{Gerasimov M.M. 1958}

Paleoliticheskaya stoyanka Malta: (Raskopki 1956-1958 gg.). Sovetskaya etnographiya, No. 3: 28-52.

\section{Konstantinov M.V. 1994}

Kamenniy vek vostochnogo regiona Baikalskoy Azii. UlanUde, Chita: Izd. Inst. obschestv. nauk BNC SO RAN.

Lbova L.V. 2018

Pigmenty i pigmentosoderzhashchiye materialy v Maltinskoy kollektsii. In Yevraziya v kainozoye: Stratigrafiya, paleoekologiya, kultury, iss. 7. Irkutsk: Izd. Irkutsk. Gos. Univ., pp. 134-141.

\section{Lbova L.V., Kulik N.A., Gubar Y.S. 2018}

Petrograficheskiy i spektralniy analiz pigmentsoderzhashchikh materialov v sostave kollektsii Maloy Syi. In Problemy arkheologii, etnografii, antropologii Sibiri $i$ sopredelnykh territoriy, vol. 24. Novosibirsk: Izd. IAET SO RAN, pp. 115-118.

Paleolit Yeniseya: Listvenka. 2005

E.V. Akimova, N.I. Drozdov, V.P. Chekha, S.A. Laukhin, L.A. Orlova, A.F. Sanko, E.A. Shpakova. Krasnoyarsk: Univers.

Pitulko V.V., Pavlova E.Y., Nikolsky P.A.,

Ivanova V.V. 2012

Yanskaya stoyanka: Materialnaya kultura i simvolicheskaya deyatelnost verkhnepaleoliticheskogo naseleniya Sibirskoy 
Arktiki. In Rossiyskiy arkheologicheskiy yezhegodnik, No. 2. St. Petersburg: Izd. Sankt-Petersburg. Gos. Univ., pp. 33-102.

Pomies M.-P., Menu M., Vignaud C. 1999

Red Paleolithic pigment: Natural hematite or heated goethite? Archaeometry, vol. 41 (2): 275-285.

Potter B.A., Irish J.D., Reuther J.D.,

McKinney H.J. 2014

New insights into Eastern Beringian mortuary behavior: A terminal Pleistocene double infant burial at Upward Sun River. Proceedings of the National Academy of Sciences, vol. 111 (48): 17060-17065.

Pradeau J.-V., Salomon H., Bon F., Mensan R., Lejay M., Regert M. 2014

Les matières colorantes sur le site aurignacien de plein air de Régismont-le-Haut (Poilhes, Hérault): Acquisition, transformations et utilisations. Bulletin de la Société Préhistorique Française, vol. 111 (4): 631-658.

Reimer P.J., Bard E., Bayliss A., Beck J.W.,

Blackwel P.G., Bronk Ramsey C., Grootes P.M.,

Guilderson T.P., Haflidason H., Hajdas I., Hattž C.,

Heaton T.J., Hoffman D.L., Hogg A.G., Hughen K.A.,

Kaiser K.F., Kromer B., Manning S.W., Niu M.,

Reimer R.W., Richards D.A., Scott E.M., Southon J.R.,

Staff R.A., Turner C.S.M., Plict J., van der. 2013

IntCal 13 and marine 13 radiocarbon age calibration curves

0-50000 years cal BP. Radiocarbon, vol. 55 (4): 1869-1887.

Rudniye mestorozhdeniia Sibiri. 1978

Vol. 1. Moscow: Nedra.

Tashak V.I. 2005

Paleoliticheskiye i mezoliticheskiye pamyatniki UstKyakhty. Ulan-Ude: Izd. BNC SO RAN.

Tetenkin A.V. 2019

Planigraficheskiy analiz ochazhnogo kompleksa 2B kulturnogo gorizonta Kovrizhki IV: Rekonstruktsiya deyatelnostnoy situatsii. Multidistsiplinarniye issledovaniya $v$ arkheologii, No. 2: 26-51.
Tetenkin A.V., Henry A., Klementiev A.M. 2017

Kovrizhka IV: Pozdnepaleoliticheskiy kompleks 6 kulturnogo gorizonta. Arkheologicheskiye vesti, iss. 23: 33-55.

Tetenkin A.V., Zhmur O.V., Demonterova E.I.,

Kaneva E.V., Salnaya N.V. 2018

Ivory figurines and the symbolic context of a Paleolithic dwelling at Kovrizhka IV on the Lower Vitim River, Eastern Siberia. Archaeology, Ethnology and Anthropology of Eurasia, vol. 46 (4): 3-12.

Usacheva I.V., Adayev V.N., Kosinskaya L.L.,

Yudina E.A. 2018

Okhra v zhilishchakh kamennogo veka tayezhnoy zony Zauralya i severa Zapadnoy Sibiri: Adaptivniy aspect. In Chelovek i Sever: Antropologiya, arkheologiya, ekologiya: Materialy vseros. nauchn. konf., g. Tyumen, 2-6 apr. 2018 g., iss. 4. Tyumen: TyumNC SO RAN, pp. 254-258.

Vasiliev S.A. 1996

Pozdniy paleolit Verkhnego Yeniseya (po materialam mnogosloinykh stoyanok rayona Mainy). St. Petersburg: Petersburg. Vostokovedeniye.

Vetrov V.M. 2008

Ritualniy kompleks v ustye r. Karenga (dolina r. Vitim) i nekotoriye problemy neolita Vostochnoy Sibiri. Izvestiya Laboratorii drevnikh tekhnologiy, iss. 6: 28-43.

Zhelezorudniye mestorozhdeniya Angaro-

Ilimskogo rayona. 1953

Moscow: Izd. AN SSSR.

Zhelezorudniye mestorozhdeniya Sibiri. 1981

Novosibirsk: Nauka.

Received November 18, 2019.

Received in revised form February 14, 2020. 